Ann. rheum. Dis. (1961), 20, 235.

\title{
EPIDEMIOLOGY OF THE SHEEP CELL AGGLUTINATION TEST
}

\author{
BY \\ J. BALL AND J. S. LAWRENCE \\ From the Rheumatism Research Centre, Manchester University, \\ and the Empire Rheumatism Council's Field Unit
}

Recent research into the nature and significance of rheumatoid serum factors has been largely immunological and biochemical. The epidemiology of these components is virtually unknown. During recent years we have had the opportunity of studying several population samples, and data from these surveys have now been gathered and are presented with particular reference to the epidemiology of the serum factor which reacts with sheep cells sensitized by a rabbit anti-sheep haemolysin.

\section{Material and Methods}

The following populations have been investigated during the last 7 years and are listed below in roughly chronological order:

(1) Leigh.-Two surveys have been conducted in this mining and industrial borough in Lancashire, England:

(a) A 1 in 10 random sample drawn from the electoral roll, comprising 204 males and 277 females aged 55-64 years;

(b) A 1 in 30 random sample, also drawn from the electoral roll, of subjects aged 15 years or more, comprising 768 males and 846 females, including part of $(a)$.

Some observations on the Leigh population have already been published (Kellgren and Lawrence, 1956; Lawrence and Ball, 1958; Lawrence and Bennett, 1960).

(2) Glamorgan.-A sample comprising 100 males and 100 females aged 55-64 years from the Vale of Glamorgan, a farming area in South Wales. This is approximately a 1 in 3 sample and was chosen at random from a census undertaken by the Pneumoconiosis Research Unit.

(3) Annandale.-A sample comprising 105 males and 101 females aged 55-64 years from the rural area of Annandale in Southern Scotland. This is approximately a 1 in $\mathbf{4}$ sample and was chosen at random from a private census undertaken by Cochran, Clayson, and Fletcher (1957) in connexion with a chest survey.

(4) Rhondda.-A stratified random sample comprising 600 males aged 35-64 years and 200 females aged 55-64 years from the Rhondda Fach, a coal mining area in South Wales. The males were stratified so that there were 100 miners and 100 non-miners in each decade. This represents approximately the proportions of these workers in the area and is roughly a 1 in 7 sample of the total in each decade. Selection within the strata was random, and was taken from a census by the Pneumoconiosis Research Unit.

(5) Rotterdam.-A random sample comprising 166 males and 154 females aged 55-64 years from the City of Rotterdam, The Netherlands. These subjects were contained in a larger sample of the population aged 15-64 which was selected by taking every 50th card from the municipal register; if the person chosen was not in the 15-64 age group, the next card was taken and so forth.

(6) Wensleydale.-This was an area sample of 509 males and 553 females aged 15 years or more in the rural district of Wensleydale in Northern England. It included half the main town of Hawes and half the farms and villages in the dale.

(7) Heinola.-An approximately 1 in 2 random sample comprising 175 males and 214 females, aged 55-64 years, from the population of a rural area 70 miles North of Helsinki, Finland. The majority of the subjects in the sample lived in a village and worked in a hardboard factory. The blood samples taken were tested by various methods. In 53 of the males and 64 of the females, the blood samples were too small to allow a S.C.A.T. test to be performed, but the results obtained by other methods suggest that the sample tested by the S.C.A.T. is representative.

The sensitized sheep cell test was performed as previously described (Ball, 1950), a titre of 1 in 32 after $18 \mathrm{hrs}$ ' incubation being defined as a minimum positive result (Kellgren and Ball, 1959). The haemolysin used was either prepared by us in rabbits or obtained from Cappel Laboratories. Secular errors have been minimized by standardizing the sensitivity of the test against a series of human sera of known agglutinating activity. Titres are expressed below as the reciprocal of the serum dilution; a titre of $<4$ signifies no agglutination detected within the range of serum dilutions tested ( 1 in 4 to 1 in 4,096).

The clinical and radiological methods used have been described elsewhere (Kellgren and Lawrence, 1956; Lawrence and Ball, 1958). 


\section{Results}

Geographic Variations.-These have been studied only in the 55- to 64-year age group, since in most areas this was the only age range tested. Among seven population samples the proportion of positive titres varied between 1.6 and 5.4 per cent. (Table I). The mean prevalence of sero-positive subjects was significantly greater in urban than in rural areas $(p=<0.01)$.

In the urban populations, positive titres were equally divided between males and females. In the rural samples no definite sex preponderance emerged, though the number of positive tests was small, and a more detailed study of other age groups in the Wensleydale population (see below) did reveal a lower prevalence of positive tests in males aged over 54 years.

Age and Sex Distribution of Positive Tests.-This was studied in the Leigh $(b)$ and Wensleydale populations; in addition, the age distribution of

TABLE I

PREVALENCE OF POSITIVE TESTS IN URBAN AND RURAL POPULATIONS AGED 55 TO 64 YEARS

\begin{tabular}{|c|c|c|c|c|c|c|c|c|c|c|c|c|c|c|c|}
\hline & \multirow{3}{*}{\multicolumn{2}{|c|}{ Sample }} & \multirow{3}{*}{$\begin{array}{l}\text { Geographical } \\
\text { Latitude }\end{array}$} & \multicolumn{3}{|c|}{ Total Available Sample } & \multicolumn{3}{|c|}{ Total Tested } & \multicolumn{6}{|c|}{ Titre 32 or More } \\
\hline & & & & \multirow{2}{*}{ Males } & \multirow{2}{*}{ Females } & \multirow{2}{*}{ Both Sexes } & \multirow{2}{*}{ Males } & \multirow{2}{*}{ Females } & \multirow{2}{*}{ Both Sexes } & \multicolumn{2}{|c|}{ Males } & \multicolumn{2}{|c|}{ Females } & \multirow{2}{*}{$\frac{\text { Both }}{\text { No. }}$} & \multirow{2}{*}{$\frac{\text { Sexes }}{\%}$} \\
\hline & & & & & & & & & & No. & $\%$ & No. & $\%$ & & \\
\hline \multirow[t]{2}{*}{ Rural } & $\begin{array}{l}\text { Heinola } \\
\text { Annandale } \\
\text { Wensleydale } \\
\text { Glamorgan }\end{array}$ & $\cdots$ & $\begin{array}{ll}61^{\circ} & \mathrm{N} . \\
55^{\circ} & \mathrm{N} . \\
54^{\circ} & \mathrm{N} . \\
51^{\circ} & \mathrm{N} .\end{array}$ & $\begin{array}{r}175 \\
105 \\
63 \\
100\end{array}$ & $\begin{array}{r}214 \\
101 \\
76 \\
100\end{array}$ & $\begin{array}{l}389 \\
206 \\
139 \\
200\end{array}$ & $\begin{array}{r}104 \\
96 \\
55 \\
88\end{array}$ & $\begin{array}{r}123 \\
91 \\
62 \\
85\end{array}$ & $\begin{array}{l}245 \\
187 \\
117 \\
173\end{array}$ & $\begin{array}{l}3 \\
3 \\
0 \\
2\end{array}$ & $\begin{array}{l}2 \cdot 9 \\
3 \cdot 1 \\
0 \\
2 \cdot 3\end{array}$ & $\begin{array}{l}1 \\
1 \\
3 \\
4\end{array}$ & $\begin{array}{l}0 \cdot 8 \\
1 \cdot 1 \\
4 \cdot 8 \\
4 \cdot 7\end{array}$ & $\begin{array}{l}4 \\
4 \\
3 \\
6\end{array}$ & $\begin{array}{l}1 \cdot 6 \\
2 \cdot 1 \\
2 \cdot 6 \\
3 \cdot 5\end{array}$ \\
\hline & Total & . & & 443 & 491 & 934 & 343 & 361 & 704 & 8 & $2 \cdot 3$ & 9 & $2 \cdot 5$ & 17 & $2 \cdot 4$ \\
\hline \multirow[t]{2}{*}{ Urban } & $\begin{array}{l}\text { Leigh } \\
\text { Rhondda } \\
\text { Rotterdam }\end{array}$ & $\begin{array}{l}\cdots \\
\cdots \\
\cdots\end{array}$ & $\begin{array}{ll}53^{\circ} & \mathbf{N} . \\
52^{\circ} & \mathbf{N} . \\
51^{\circ} & \mathbf{N}\end{array}$ & $\begin{array}{l}204 \\
200 \\
166\end{array}$ & $\begin{array}{l}277 \\
200 \\
154\end{array}$ & $\begin{array}{l}481 \\
400 \\
320\end{array}$ & $\begin{array}{l}163 \\
177 \\
138\end{array}$ & $\begin{array}{l}187 \\
181 \\
133\end{array}$ & $\begin{array}{l}350 \\
358 \\
271\end{array}$ & $\begin{array}{r}8 \\
11 \\
6\end{array}$ & $\begin{array}{l}4 \cdot 9 \\
6 \cdot 2 \\
4 \cdot 3\end{array}$ & $\begin{array}{r}11 \\
7 \\
7\end{array}$ & $\begin{array}{l}5 \cdot 9 \\
3 \cdot 9 \\
5 \cdot 3\end{array}$ & $\begin{array}{l}19 \\
18 \\
13\end{array}$ & $\begin{array}{l}5 \cdot 4 \\
5 \cdot 0 \\
4 \cdot 8\end{array}$ \\
\hline & Total & $\ldots$ & & 570 & 631 & 1,201 & 478 & 501 & 979 & 25 & $5 \cdot 2$ & 25 & $5 \cdot 0$ & 50 & $5 \cdot 1$ \\
\hline
\end{tabular}

TABLE II

DISTRIBUTION OF TITRES BY AGE AND SEX IN LEIGH (b) AND WENSLEYDALE

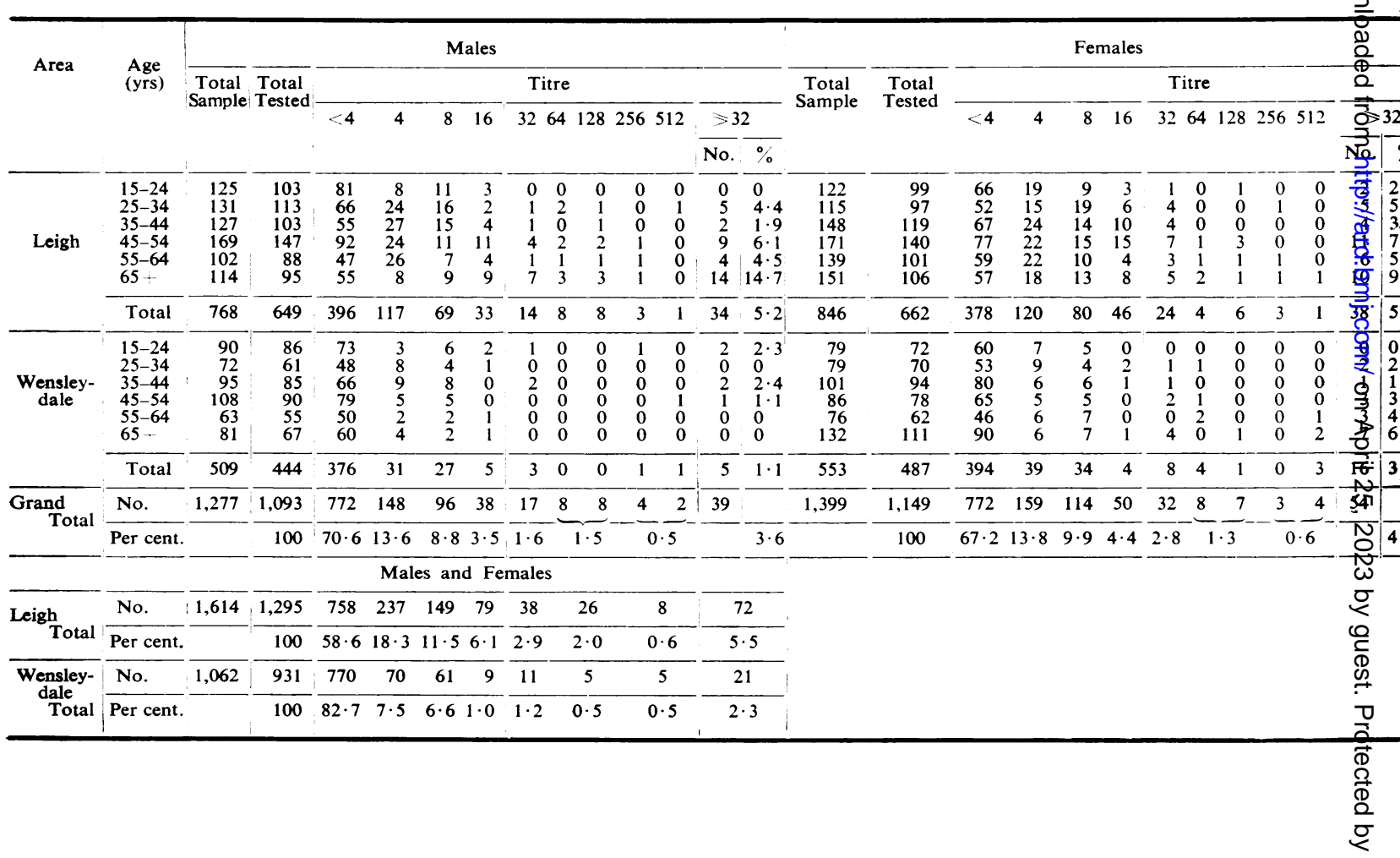


positive tests was investigated in the males of the Rhondda sample. The results are shown in Tables II and III and Figs 1 and 2 . There was a greater overall prevalence of positive tests in Leigh $(5 \cdot 5$ per cent.) than in Wensleydale ( $2 \cdot 3$ per cent.), which confirms in a more representative sample the findings regarding rural and urban populations already described for the 55- to 64-year age group (Table I). In Leigh, positive results occurred with virtually the same frequency in males and females in all age groups. In Wensleydale, however, there was a significantly greater prevalence $(p=<0.05)$ of positive tests in females (3.3 per cent.) than in males ( $1 \cdot 1$ per cent.), mainly because of the absence of positive titres in males aged over 54 years. It will be seen that the prevalence of positive tests in Leigh increased from approximately 1 per cent. in the 15- to 24-year age group to 12 per cent. in subjects aged 65 or over. This increase with age was present in both males and females (Fig. 1). An increase with age was also found in the males in the Rhondda sample and in the Wensleydale females, but in the Wensleydale males there were no positive tests among subjects aged 55 or over (Fig. 2).

In males and females in Leigh, the trend upwards in the prevalence of positive tests with age presented two peaks spaced at an interval of about 20 years (Fig. 1). The differences producing the peaks do not reach statistically significant levels.

TABLE III

DISTRIBUTION OF TITRES BY AGE IN RHONDDA MALES

\begin{tabular}{|c|c|c|c|c|c|c|c|c|c|c|c|c|c|}
\hline \multirow{3}{*}{$\begin{array}{c}\text { Age } \\
\text { (yrs) }\end{array}$} & \multirow{3}{*}{$\begin{array}{c}\text { Total } \\
\text { Sample }\end{array}$} & \multirow{3}{*}{$\begin{array}{l}\text { Total } \\
\text { Tested }\end{array}$} & \multicolumn{11}{|c|}{ Titre } \\
\hline & & & \multirow[t]{2}{*}{$<4$} & \multirow[t]{2}{*}{4} & \multirow[t]{2}{*}{8} & \multirow[t]{2}{*}{16} & \multirow[t]{2}{*}{32} & \multirow[t]{2}{*}{64} & \multirow[t]{2}{*}{128} & \multirow[t]{2}{*}{256} & \multirow[t]{2}{*}{512} & \multicolumn{2}{|c|}{$>32$} \\
\hline & & & & & & & & & & & & No. & $\%$ \\
\hline $35-44$ & 200 & 162 & 142 & 8 & 7 & 2 & 1 & 0 & 0 & 2 & 0 & 3 & 1.9 \\
\hline $45-54$ & 200 & 184 & 166 & 7 & 6 & 2 & 3 & 0 & 0 & 0 & 0 & 3 & $1 \cdot 6$ \\
\hline $55-64$ & 200 & 179 & 150 & 9 & 6 & 3 & 4 & 3 & 1 & 1 & 2 & 11 & $6 \cdot 1$ \\
\hline
\end{tabular}

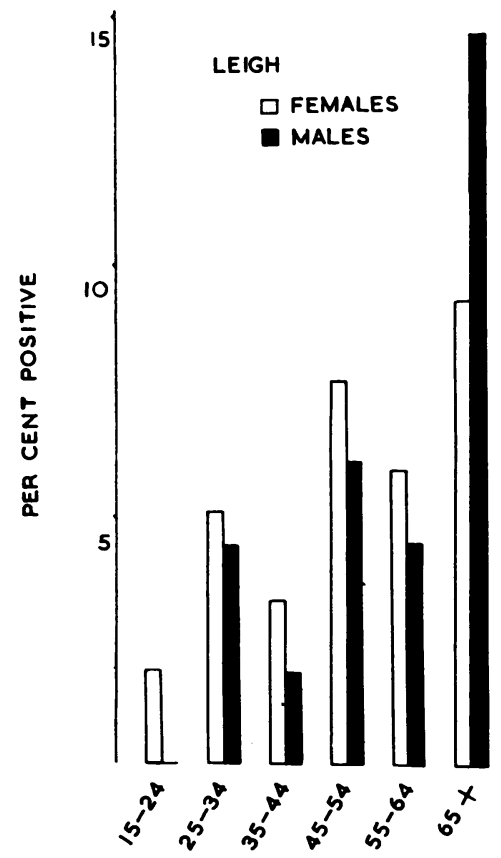

Fig. 1.-Prevalence of positive tests by age and sex in Leigh (b).

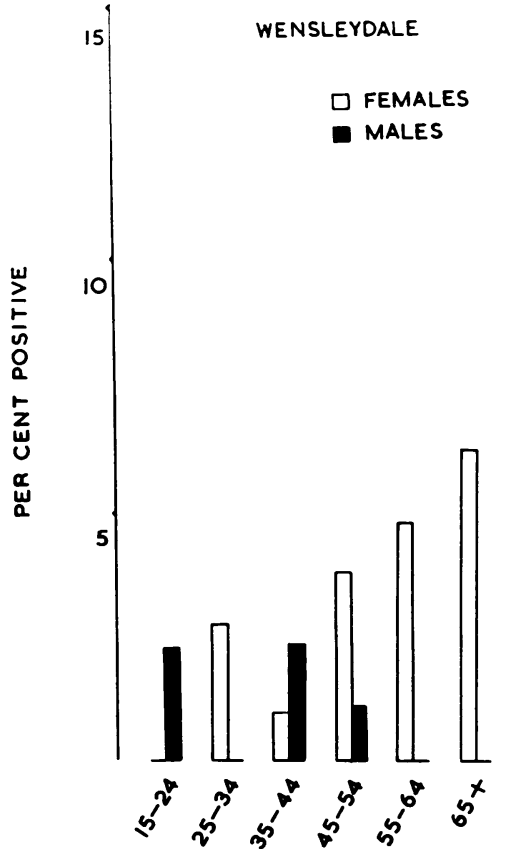

Fig. 2.-Prevalence of positive tests by age and sex in Wensleydale. 
Distribution of Titres.-This is shown for the Leigh $(b)$ and Wensleydale populations in Table II and Figs 3 and 4 . In Leigh, which is the larger sample, the titre distribution follows a simple curve; the curve for Wensleydale is uneven, but there is no definite evidence of bimodality (Fig. 3). In the combined Leigh and Wensleydale sample (Fig. 4) the titre distribution similarly forms a simple curve which is virtually identical in males and females. It can be seen (Fig. 3) that the curve for Leigh (in which there was a higher overall prevalence of positive tests than in Wensleydale) is set at a higher level than the curve for Wensleydale at all agglutination titres. These findings do not suggest a qualitative difference between low and high titre agglutination.

Agglutination of some degree occurred in about 17 per cent. of the Wensleydale sample and in about 40 per cent. of the Leigh $(b)$ population.

Genetic Factors.--The possibility that rheumatoid factor is subject to genetic influences was investigated in the Leigh sample by comparing the titre distribution among the first degree relatives (parents, siblings, and offspring) with those of the propositi. All sero-positive individuals in the sample were chosen. The sero-negative propositi included healthy

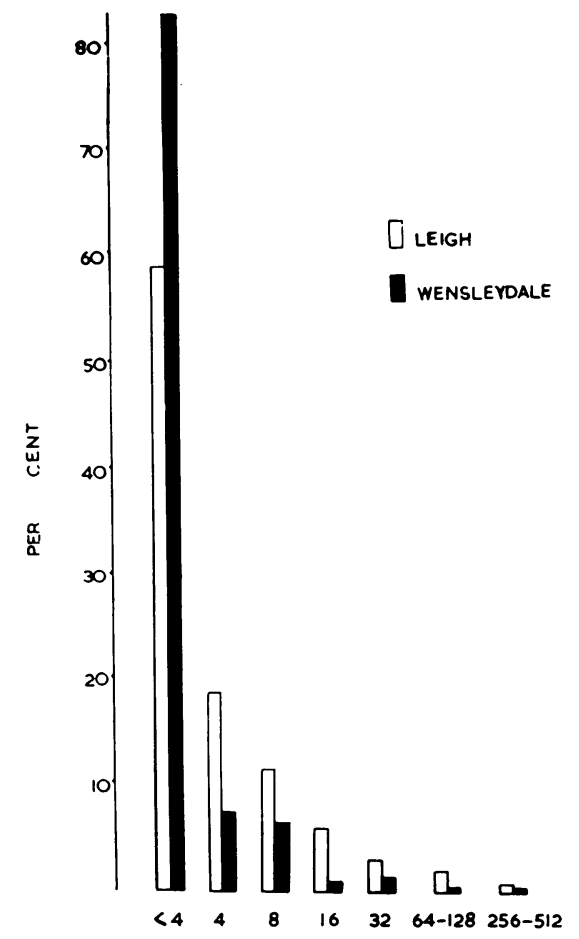

Fig. 3.-Titre distribution in Leigh $(b)$ and Wensleydale, all age groups and both sexes combined. individuals and subjects suffering from rheumatoid arthritis or other diseases. Table IV (opposite) shows that the proportion of sero-positive relatives increases as the titre of the propositi increases above 4 . Thus, 12 per cent. of relatives of propositi with a titre of 128 or more were positive as compared with 3 per cent. of relatives of propositi with titres of 4 or less, the difference being significant at the 1 per cent. level. This difference is not likely to be due to differences in the age distribution of relatives in the two titre groups compared (Table V, opposite).

In an attempt to exclude an environmental cause of the observed familial aggregation of seropositivity, the results in married persons were considered. Among 1,200 married persons, positive titres were found in 4 per cent.; thus, by chance alone, both spouses would be expected to be positive once in 625 couples. In fact, two couples were found in which both husband and wife were positive.

Relation of the Titre to the Diagnostic Criteria of Rheumatoid Arthritis.-This was studied in the combined Leigh $(b)$ and Wensleydale sample. The diagnosis of rheumatoid arthritis was based on the American Rheumatism Association's criteria (Ropes, Bennett, Cobb, Jacox, and Jessar, 1959), except thab 
TABLE IV

RELATION OF TITRES IN RELATIVES AND PROPOSITI

\begin{tabular}{|c|c|c|c|c|c|c|c|c|}
\hline & \multirow{3}{*}{ Propositi } & \multicolumn{7}{|c|}{ Relatives } \\
\hline & & \multirow[b]{2}{*}{ Total in Sample } & \multirow[b]{2}{*}{ Total Tested } & \multicolumn{5}{|c|}{ Titre of Those Tested } \\
\hline & & & & $<4$ & $4-16$ & $32-64$ & $128-512$ & $\begin{array}{c}\text { Percentage } \\
>32\end{array}$ \\
\hline \multirow{9}{*}{ Titre } & $<4$ & 363 & 207 & 131 & 71 & 4 & 1 & \multirow{2}{*}{3} \\
\hline & 4 & 99 & 87 & 64 & 20 & 2 & 1 & \\
\hline & 8 & 42 & 39 & 27 & 10 & 1 & 1 & \multirow{2}{*}{6} \\
\hline & 16 & 31 & 23 & 8 & 13 & 1 & 1 & \\
\hline & 32 & 158 & 124 & 82 & 29 & 9 & 4 & \multirow{2}{*}{10} \\
\hline & 64 & 60 & 32 & 21 & 9 & 2 & 0 & \\
\hline & 128 & 59 & 40 & 21 & 15 & 4 & 0 & \multirow{3}{*}{12} \\
\hline & 256 & 33 & 26 & 14 & 8 & 2 & 2 & \\
\hline & 512 & 11 & 8 & 6 & 1 & 1 & $\mathbf{0}$ & \\
\hline
\end{tabular}

TABLE V

DISTRIBUTION OF RELATIVES BY AGE

\begin{tabular}{|c|c|c|c|c|c|c|c|c|c|c|c|c|}
\hline \multirow{4}{*}{\multicolumn{2}{|c|}{ Propositi }} & \multirow{4}{*}{$\begin{array}{l}\text { Total in } \\
\text { Sample }\end{array}$} & \multirow{4}{*}{$\begin{array}{c}\text { Total } \\
\text { Tested }\end{array}$} & \multicolumn{9}{|c|}{ Relatives } \\
\hline & & & & \multicolumn{9}{|c|}{ Age of Those Tested (yrs) } \\
\hline & & & & \multirow[b]{2}{*}{$15-24$} & \multirow[b]{2}{*}{$25-34$} & \multirow[b]{2}{*}{$35-44$} & \multirow[b]{2}{*}{$45-54$} & \multirow[b]{2}{*}{$55-64$} & \multirow[b]{2}{*}{$65+$} & \multicolumn{3}{|c|}{ Percentages } \\
\hline & & & & & & & & & & $45+$ & $55+$ & $65+$ \\
\hline \multirow{4}{*}{ Titre } & $<4-4$ & 462 & 294 & 19 & 60 & 53 & 40 & 76 & 46 & 55 & 38 & 15 \\
\hline & $8-16$ & 73 & 62 & 11 & 13 & 14 & 3 & 8 & 13 & 39 & 34 & 20 \\
\hline & $32-64$ & 218 & 156 & 18 & 23 & 39 & 33 & 17 & 26 & 49 & 28 & 16 \\
\hline & $128-256$ & 103 & 74 & 5 & 17 & 6 & 25 & 12 & 9 & 62 & 28 & 12 \\
\hline
\end{tabular}

in computing the score the point normally given for a positive S.C.A.T. was excluded; the diagnosis of rheumatoid arthritis was thus in this sense rather more strict than would normally be the case. The results are shown in Table VI. Among the 2,242 persons tested, 93 were sero-positive, but of these only eighteen ( 19.4 per cent.) had definite or probable rheumatoid arthritis (i.e. at least three A.R.A. criteria, not counting the S.C.A.T. point). As expected, the prevalence of definite or probable rheumatoid arthritis increased sharply in the titre groups above 16 , a finding which, parenthetically, validates the choice of a titre of 32 as the minimum positive titre in this laboratory.

5 years after the Leigh (a) survey was completed, 57 subjects originally aged 55-64 years, were chosen for follow-up. They included the nineteen seropositive subjects and a sample of 38 sero-negative subjects, each serological group containing clinical
TABLE VI

S.C.A.T. TITRE AND AMERICAN RHEUMATISM ASSOCIATION'S CRITERIA

\begin{tabular}{c|c|c|c}
\hline Titre & $\begin{array}{c}\text { Total } \\
\text { No. }\end{array}$ & $\begin{array}{c}\text { At Least Three A.R.A. Criteria } \\
\text { (not including S.C.A.T. point) }\end{array}$ \\
\cline { 2 - 3 } & $\begin{array}{c}\text { No. } \\
\text { Sorcentage of Total }\end{array}$ \\
\hline$<4$ & 3,544 & 54 & $3 \cdot 5$ \\
\hline 4 & 307 & 10 & $3 \cdot 3$ \\
\hline 8 & 210 & 8 & $3 \cdot 8$ \\
\hline 16 & 88 & 3 & $3 \cdot 4$ \\
\hline$<4-16$ & 2,149 & 75 & $3 \cdot 5$ \\
\hline 32 & 49 & 4 & $8 \cdot 2$ \\
\hline $64-128$ & 31 & 5 & $16 \cdot 1$ \\
\hline $256-512$ & 13 & 9 & $69 \cdot 3$ \\
\hline $32-512$ & 93 & 18 & $19 \cdot 4$ \\
\hline
\end{tabular}


rheumatoid arthritic and non-rheumatoid individuals. Of these, four had died and twelve could not be re-tested. None of the latter had changed clinically. Of the four who died, three were originally S.C.A.T. negative and none of the four had clinical rheumatoid arthritis. It will be seen (Table VII) that twelve of the initially S.C.A.T.positive and 29 of the initially S.C.A.T.-negative subjects were re-assessed in 1959: Of the seven S.C.A.T.-positive non-rheumatoid subjects two were found to have developed the disease in the interval, but of the 25 S.C.A.T.-negative non-rheumatoid subjects none had developed rheumatoid arthritis. On the other hand, two of four subjects initially classified as suffering from S.C.A.T.-negative rheumatoid arthritis had gone into remission, whereas of the five subjects initially falling in the S.C.A.T.positive rheumatoid arthritic group, none had remitted-one had in fact deteriorated.

\section{Discussion}

The prevalence of positive S.C.A.T. results varied only between 1.6 and 5.4 per cent. in several European population samples aged 55-64 years; there was, nevertheless, a significantly greater prevalence in urban than in rural areas (Table I). This finding was confirmed in a comparison of urban (Leigh) and rural (Wensleydale) samples which included all age groups over 15 years, the difference being particularly marked in males aged over 54 years (Table II). Both males and females in Leigh are exposed to a much heavier industrial pollution of the atmosphere than are the people of Wensleydale. Most of the females in Leigh and Wensleydale are occupied in their homes, but whereas the Leigh males work in mines or in various manufacturing industries, the Wensleydale males are employed mainly in the open air on farms or on the roads and railways. There may thus be a greater occupational difference between urban and $\overline{\overline{3}}$ rural males than females.

The S.C.A.T. titre appears to be influenced by. genetic factors. In Leigh the proportion of positive titres among first-degree relatives increased as the titre of the propositi increased, and was four times greater in relatives of propositi with a titre of $128 \overline{\bar{n}}$. or more than in relatives of propositi with titres of 4 or less (Table IV). This familial aggregation dido not appear to be due to environmental factors-ates least in adult life-as judged by the prevalence of 0 positive titres in spouses. Nor does it appearto depend on the clinical state of the propositus. $\vec{\sigma}_{\mathscr{\sigma}}$ since we have previously found a similar degree of familial aggregation among relatives of botho rheumatoid and non-rheumatoid sero-positive in 0 dividuals contained in a random sample (Lawrence and Ball, 1958). No similar genetic study of thisw rheumatoid factor has been reported, but Robecch and Daneo (1959) and Bremner, Alexander, andP Duthie (1959) have performed sheep cell agglutina- $\vec{c}$ tion tests on the serum of relatives of sero-positive and sero-negative rheumatoid arthritics attendingत् hospital. Robecchi and Daneo found that $32 \cdot 1 \frac{3}{6}$ per cent. of the relatives of sero-positive rheumatoid@ arthritics had a titre of 32 or more as compargd with $17 \cdot 3$ per cent. of the relatives of sero-negatien rheumatoid propositi. Bremner and others (19) found positive results in 1.8 per cent. of 109 relatieso of sero-negative rheumatoid propositi and in 4.4 per cent. of 91 relatives of sero-positive rheumatoid, propositi, the difference being statistically non- $\frac{0}{\mathbb{Q}}$ significant. The low level of sero-positivity found 0 by Bremner and others was not due to the sero $\overrightarrow{\overrightarrow{0}}$ logical method used, since in a small series of serum? samples tested concurrently by Bremner and others and by us, essentially similar results were obtained? The failure to find definite statistical evidence of familial aggregation may simply mean that the

TABLE VII

LEIGH 5-YEAR FOLLOW-UP STUDY

\begin{tabular}{|c|c|c|c|c|c|c|c|c|c|}
\hline \multirow{4}{*}{$\begin{array}{c}\text { S.C.A.T. } \\
\text { Results }\end{array}$} & \multicolumn{2}{|c|}{1954 Assessment } & & & \multicolumn{5}{|c|}{ Re-assessment in 1959} \\
\hline & \multirow{3}{*}{$\begin{array}{l}\text { Clinical } \\
\text { Rheumatoid } \\
\text { Arthritis }\end{array}$} & \multirow{3}{*}{ Males } & \multirow{3}{*}{ Females } & \multirow{3}{*}{ Total } & \multirow{3}{*}{$\begin{array}{c}\text { Total } \\
\text { Re-assessed }\end{array}$} & \multirow{2}{*}{\multicolumn{2}{|c|}{$\frac{\text { S.C.A.T.-Positive }}{\text { Clinical Rheumatoid Arthritis }}$}} & \multirow{2}{*}{\multicolumn{2}{|c|}{$\frac{\text { S.C.A.T.-Negative }}{\text { Clinical Rheumatoid Arthritis }}$}} \\
\hline & & & & & & & & & \\
\hline & & & & & & Present & Absent & Present & Absent \\
\hline \multirow{2}{*}{ Positive } & Present & 3 & 5 & 8 & 5 & 4 & 0 & 1 & 0 \\
\hline & Absent & 5 & 6 & 11 & 7 & 2 & 4 & 0 & 1 \\
\hline \multirow{2}{*}{ Negative } & Present & 1 & 4 & 5 & 4 & 0 & 0 & 2 & 2 \\
\hline & Absent & 17 & 16 & 33 & 25 & 0 & 0 & 0 & 25 \\
\hline Total & $\ldots$ & 26 & 31 & 57 & 41 & 6 & 4 & 3 & 28 \\
\hline
\end{tabular}


sample tested by Bremner and others was too small. On the other hand it could mean that their sample was qualitatively different, in the sense that their propositi included a larger number of subjects in which sero-positivity was environmentally rather than genetically determined; there is no evidence that this was the case, but such a circumstance, if it occurred, would obscure evidence of genetic factors. There is suggestive evidence that seropositivity may in fact be predominantly genetically determined in some and environmentally determined in others. Seropositivity is more common in healthy members of the general population than in those who suffer from, or have a history of, rheumatic disease at the time of the test; and our results indicate that in these healthy subjects the seropositivity may be genetically determined. On the other hand, among three pairs of identical twins, whose sera were examined by us through the courtesy of Dr. A. St. J. Dixon, the S.C.A.T. was positive in one twin in two pairs and in both twins in the remaining pair, indicating that non-genetic factors may affect the S.C.A.T. titre, causing or preventing the development of a positive test. Furthermore, among rheumatoid arthritics attending hospital, sero-positivity (in our laboratory) may develop long after the onset of the disease (Dixon, 1960). In experimental animals, the S.C.A.T. titre appears to be influenced by both constitutional and acquired factors, since increased S.C.A.T. titres have been induced by injection of certain bacteria, but only a proportion of the animals may react in this way (Lerner, Bloch, and Williams, 1960; Abruzzo and Christian, 1961).

Ziff, Schmid, Lewis, and Tanner (1958) have reported familial aggregation of a serum factor agglutinating tanned sheep erythrocytes coated with human $\gamma$ globulin (Cohn fraction II); and a similar result was obtained by them with a test which measures the ability of human serum to inhibit the agglutination of sensitized sheep cells. It is, however, uncertain that these tests can be equated with the procedure used by us: absence of inhibition has not been proved to be due of necessity to amounts of agglutinating factor not detectable in the direct test (Vaughan and Good, 1958; Vaughan, 1959); and it is known that sera may sometimes react with human $\gamma$ globulin but fail to react with sheep cells sensitized with rabbit haemolysin (Peltier and Christian, 1959; Kunkel, Simon, and Fudenberg, 1958). In this connexion it seems important to mention that Goldenberg, Singer, and Plotz (1960) claim to have detected evidence of familial aggregation when sera were examined by sheep cells sensitized by rabbit haemolysin but not when the same sera were tested with reagents utilizing human $\gamma$ globulin in the form either of Cohn fraction II or incomplete anti-D serum.

In the urban samples, positive S.C.A.T. results were distributed equally between males and females; in both sexes the proportion of positive titres was greater in the older age groups. This relation to age was not due to the selective survival of seropositive individuals, since the absolute number of positive tests was also greater in the older age groups. The observed difference with age could, however, be due to the one-time operation of factors which leave a permanently raised titre, but which are currently dying out. Because of this, and in the absence of a more prolonged sequential study of individual members of the population, it is not possible to conclude that the titre increases with advancing years. In the single rural (Wensleydale) sample in which all age groups over 15 years were examined, the prevalence of sero-positive subjects was lower in males than females, mainly because no males aged over 54 years were sero-positive in this particular rural sample.

In both Leigh and Wensleydale, the distribution of titres followed a simple curve in males and females. Moreover, in the Leigh sample, in which there was a greater prevalence of positive S.C.A.T. results, the titre curve was set at a higher level in both the negative and positive titre ranges. These findings suggest that the factor measured by the test may be a continuous variable and that differences in titre mainly reflect differences in degree of activity of the same serum factor. If so, this factor appears to be present in greater or lesser degree in 17 to 40 per cent. of the adult population. Absence of agglutination with the present method does not, however, signify absence of agglutinating factor because of the relatively low sensitivity of the test procedure. By increasing the concentration of amboceptor we have, in fact, been able to induce agglutinating activity in an appreciable proportion of sera with a titre of less than 4 in the present method. It has been argued on theoretical grounds that agglutination in low serum dilutions may be due to non-specific factors (Vaughan, 1959); and Heller, Jacobson, and Kolodny (1949) claimed that the titre of most rheumatoid sera was enhanced by sheep serum, but that the titre of (weakly reacting) non-rheumatoid sera was not. It seemed important, therefore, to find out the effect of sheep serum on sera having various titres in the S.C.A.T. When the saline diluent in our test procedure was replaced by 1 to 5 per cent. sheep serum in saline, 52 per cent. of 25 sera having titres in saline of 4 to 16 showed at least a 4-fold enhancement of titre as compared 
with 67 per cent. of 36 sera with titres in saline of 32 to 1,024 (unpublished observations). Thus, in terms of their susceptibility to titre enhancement by sheep serum, no sharp distinction can be drawn between sera which in our test procedure have titres of 4 to 16 and those with higher titres. This result supports the conclusions derived from a consideration of the titre distribution curve.

Only about 20 per cent. of 93 sero-positive individuals in a large population sample presented clinical or radiological evidence of rheumatoid arthritis. It would seem, therefore, that there are more healthy individuals with a positive test than rheumatoid arthritics. Nevertheless, the prevalence of rheumatoid arthritis rose sharply, as expected, in the titre groups above 16.

Two of seven sero-positive non-rheumatoid subjects in the Leigh random sample were found to have developed rheumatoid arthritis when examined 5 years later. Significant serological titres may thus antedate clinical evidence of rheumatoid disease. Among nine rheumatoid arthritics included in the five-year follow-up, out of five initially sero-positive subjects one had deteriorated, and out of the four initially classified as sero-negative, two were found to have gone into remission. Sero-positive individuals may thus be more prone to develop rheumatoid arthritis, and sero-positive arthritics may fare worse than sero-negative arthritics, but a much larger series must be studied to prove this. The present findings are, however, in accord with those of Kellgren (1957) and Duthie, Brown, Knox, and Thompson (1957), who have presented evidence for the relatively poor prognosis of sero-positive rheumatoid disease.

\section{Summary}

(1) The titre of the rheumatoid serum factor detected by sheep cells sensitized by rabbit haemolysin was determined in subjects aged 55 to 64 years in seven European population samples. Positive titres occurred in 1.6 to 5.4 per cent. of the subjects tested. The prevalence of positive tests was significantly greater in urban than rural populations. In these urban and rural samples, the proportion of positive reactors was similar in males and females.

(2) In an urban sample including all age groups over 15 years, positive tests were also equally distributed among males and females; but in the single rural sample with this age range positive tests occurred more frequently in females than in males.

(3) The prevalence of positive tests increased with age in two urban samples; a similar result was obtained among females, but not among males, in the single rural sample.
(4) The titre distribution curve in rural an urban populations suggests that the serum factor is a continuous variable present in some degree in 17 to 40 per cent. of adults and possibly more.

(5) The titre was determined in the first-degreo relatives of 261 members of an urban populatio sample. Positive titres occurred in 3 per cen $\overline{\bar{p}}$ of relatives of propositi with a titre of up to 4 , an $\overline{8}$ in 12 per cent. of relatives of propositi with a titro of 128 and more. Since positive tests in both husband and wife were not found more frequently tha? would be expected by chance, it was concluded that genetic rather than environmental factors were responsible for the observed familial aggregation of positive titres.

(6) Only about 20 per cent. of sero-positive individuals in random samples presented evidenck of rheumatoid arthritis as defined by the criterifeck of the American Rheumatism Association.

We wish to thank the staff of the Medical Research Council's Pneumoconiosis Research Unit, Penartks Dr. J. Cochran of Dumfries, Dr. Joan M. Bremner $\mathbb{\Phi}$ Leeds University, Dr. V. Laine of Heinola, and D $\overrightarrow{\mathbb{B}}$ R. de Graaff of The Hague, for providing blood sample and certain clinical data collected by them in the course of population studies. Our thanks are also due to \$isf F. Bier of the Manchester Rheumatism Research Ceref for statistical advice.

\section{REFERENCES}

Abruzzo, J. L., and Christian, C. L. (1961). Rheum., 4, 103.

Ball, J. (1950). Lancet, 2, 520.

Bremner, J. M., Alexander, W. R. M., and Duthie J. J. R. (1959). Ann. rheum. Dis., 18, 279.

Cochran, J. B., Clayson, C., and Fletcher, W. B. (1957) Brit. med. J., 2, 185.

Dixon, A. St. J. (1960). Ann. rheum. Dis., 19, 209.

Duthie, J. J. R., Brown, P. E., Knox, J. D. E., an Thompson, M. (1957). Ibid., 16, 411.

Goldenberg, A., Singer, J. M., and Plotz, C. M. (1960룰 Annual Meeting of American Rheumatisn. Association, June, 1960, p. 39.

Heller, G., Jacobson, A. S., and Kolodny, M. H. (1949믈 Proc. Soc. exp. Biol. (N.Y), 72, 316.

Kellgren, J. H. (1957). Brit. med. J., 1, 850.

and Ball, J. (1959). Ibid., 1, 523. and Lawrence, J. S. (1956). Ann. rheum. Dis 15,1 .

Kunkel, H. G., Simon, H. J., and Fudenberg, H. (1958). Arthr. and Rheum., 1, 289.

Lawrence, J. S., and Ball, J. (1958). Ann. rheum. Dis N్ $17,160$.

- and Bennett, P. H. (1960). Ibid., 19, 20.

Lerner, E. M., Bloch, K. J., and Williams, R. R. (1960) Arthr. and Rheum., 3, 26.

Peltier, A., and Christian, C. L. (1959). Ibid., 2, 1.

Robecchi, A., and Daneo, V. (1959). Acta rheum scand., 5, 245. 
Ropes, M., Bennett, G. A., Cobb, S., Jacox, R., and Jessar, R. A. (1959). Ann. rheum. Dis., 18, 49.

Vaughan, J. H. (1959). Amer. J. Med., 26, 596. and Good, R. A. (1958). Arthr. and Rheum., 1, 99.

Ziff, M., Schmid, F. R., Lewis, A. J., and Tanner, M. (1958). Ibid., 1, 392.

\section{Epidémiologie de la réaction d'agglutination des globules de mouton}

\section{RÉSUMÉ}

(1) On détermina le titre du facteur rhumatismal sérique révélé par l'agglutination des globules rouges de mouton par l'hémolysine de lapin dans sept échantillons de la population européenne, chez des sujets âgés entre 55 et 64 ans. On obtint des titres positifs chez 1,6 à 5,4 pour cent des sujets examinés. Le pourcentage des reactions positives fut appréciablement supérieur parmi les populations urbaines que parmi les rurales. Dans les deux types de population la proportion des résultats positifs chez des hommes et des femmes fut similaire.

(2) Dans un échantillon de population urbaine comprenant tous les âges au dessus de 15 ans, les résultats positifs furent repartis également entre les deux sexes, mais dans un échantillon unique de population rurale avec une échelle d'âges similaire, les réactions positives furent plus fréquentes parmi les femmes.

(3) On nota une augmentation du nombre des réactions positives avec l'âge dans deux échantillons de population urbaine; un résultat similaire fut obtenu parmi les femmes, mais non pas parmi les hommes, dans le seul échantillon de population rurale.

(4) La courbe de distribution des titres dans des populations rurales et urbaines indique que le facteur sérique est une variable continue présente à un certain degré en 17 à 40 pour cent de la population adulte et, peut-être, plus que ça.

(5) On détermina le titre d'agglutination chez de proches parents de 261 membres d'un échantillon de population urbaine. Ces titres furent positifs en 3 pour cent des parents des sujets avec un titre de 4 et en 12 pour cent des parents des sujets avec un titre de 128 ou plus. Puisque des réactions positives chez les deux époux ne furent pas trop fréquentes, on conclut que l'agrégation familiale des titres positifs est due plus aux facteurs génétiques qu'ambiants.

(6) Seulement 20 pour cent à peu près des sujets séropositifs trouvés dans des échantillons pris au hasard présentait un tableau d'arthrite rhumatismale définie par les critères de la American Rheumatism Association.

\section{Epidemiología de la reacción de aglutinación de los eritrocitos de carnero \\ Sumario}

(1) Se determinó et título del factor reumatoide sérico revelado por la aglutinación de los eritrocitos de carnero sensibilizados con hemolisina de conejo en siete muestras de poblacion de Europa, en indivíduos de edades comprendidas entre 55 y 64 años. Aparecieron títulos positivos en el 1,6 a 5,4 por ciento de los sujetos examinados. El porcentaje de reacciones positivas fué significativamente superior entre las poblaciones urbanas que entre las rurales. En ambos tipos de población la proporción de positividades en hombres y mujeres fué similar.

(2) En una muestra de población urbana incluyendo todas las edades por encima de 15 años, los resultados positivos estuvieron repartidos por igual entre ambos sexos, pero en una sola muestra de población rural, con una escala de edades similar, las reacciones positivas fueron más frecuentes entre las mujeres.

(3) Se apreció un incremento de número de reacciones positivas con el aumento de edad en dos muestras de población urbana; un resultado similar se obtuvo entre las mujeres, pero no entre los hombres, en una sola muestra de población rural.

(4) La curva de distribución de los títulos en poblaciones rurales y urbanas sugiere que el factor sérico es una variable continua presente en cierto grado entre el 17 al 40 por ciento de la población adulta y posiblemente más.

(5) Se determinó el título de aglutinación en los los familiares de primer grado de 261 miembros de una muestra de población urbana. Entre los familiares de sujetos con un título de aglutinación de hasta 4 se encontró un 3 por ciento de títulos positivos, y un 12 por ciento entre los familaires de aquellos indivíduos con títulos de 128 y más. Como reacciones positivas en ambos cónyuges no aparecieron con una frecuencia superior a la que es de esperar por factores de azar, se concluyó que la agregación familiar de títulos positivos observada era debida más a factores genéticos que a ambientales.

(6) Solamente alrededor del 20 por ciento de los individuos seropositivos encontrados en muestras tomadas al azar, presentaban el cuadro de artritis reumatoide, aplicando el criterio de la American Rheumatism Association. 